\title{
INTERGRATION OF ASWAJA TEACHING: CONCEPT OF STRENGTHENING CHARACTER EDUCATION IN COLLEGE
}

\author{
Fitria Martanti \\ Universitas Wahid Hasyim Semarang \\ fitriamartanti@unwahas.ac.id
}

\begin{abstract}
Planting of character education must be carried out continuously. The characters that have been planted in school must be strengthened in college. The planting of character education must be taught, familiarized, trained consistently, become character and become a culture, so that the planting of education is not only in school, but must be strengthened into a culture in college. Strengthening the character in college should be more endeavored to make students who are faithful, pious, noble, moral, ethical and civilized based on the nation's noble values of religion, Pancasila, the Constitution of 1945 and the culture of moderating Islamic values. The noble values of the nation from religion and the culture of Islamic values of moderation can be seen from the Aswaja teachings that can be embedded in the teachings that can strengthen character education in universities. This research is a qualitative research conducted at Wahid Hasyim University, Semarang, which is
\end{abstract}


one of the universities that base Aswaja as a foundation for strengthening character education. The source of the data is obtained from primary and secondary data. Data collection method is done by interview, documentation and observation, while data analysis method uses descriptive analysis method. The results of the study show that the concept of aswaja teaching at Wahid Hasyim University is used as the foundation that underlies all activities carried out on campus, both matters relating to aqidah, worship/sharia, and morals. As for strengthening character education through Aswaja teachings, it was carried out by making Aswaja Center which regulates activities related to Aswaja. The implementation of the Aswaja teachings is carried out through habituation, guidance and consultation related to religious practices. Aswaja's teachings are also integrated in courses according to each faculty.

Key Words : Aswaja, Education, Character.

\section{Preliminary}

\section{A. Background}

Character education is a central issue in the provision of education in Indonesia. Not only is the implementation of education at the elementary level, junior high school and high school also a priority in the implementation of education in Indonesia. The basis for organizing character education at all levels is mainly because the government applies character 
education nationally and integrates its implementation in the applicable curriculum in Indonesia.

The most important thing that is of concern is certainly related to the ongoing implementation of character education. The character will be formed from the internalization of values that are consistent or there is harmony between the value elements. Each value is in a spectrum or group of values, so psychologically and socioculturally a value must be coherent with other valuesin the group to form a complete character. ${ }^{1}$ Understanding this, the character values that have been taught in the school environment must always be strengthened at the University.

Character cultivation that has been done in the school environment through various activities, must be strengthened in the implementation of education in higher education, especially in practicing tri dharma of higher education, organizational culture, student activities and daily activities. ${ }^{2}$

Strengthening character education in higher education is a must because students have the main role and function in society, namely as agents of change, social control and moral force. Seeing the role and function of students who are so urgent in society, it has become a necessity that students must have good character. The good character of a student can only be obtained where education held in the scope of higher

1 Agus Wibowo, Pendidikan Karakter di Perguruan Tinggi, (Yogyakarta: Pustaka Pelajar, cet.1, 2014), page 144

${ }^{2}$ Tim Pendidikan Karakter Ditjen Dikti 2010 
education is carried out in accordance with the national policy direction of national character development.

Basically character education in higher education must be sought to make students who are faithful, pious, noble, moral, ethical and civilized based on the noble values of the religion, the Pancasila, the 1945 Constitution and the culture of values of Islamic moderation. The noble values of the nation from religion and the culture of Islamic values of moderation can be seen from the Aswaja teachings that can be embedded in teachings that can strengthen character education in higher education.

One of the higher education institutions that based Aswaja's teachings as a foundation in strengthening character education for students is Wahid Hasyim University, Semarang. Based on the results of preliminary observations it can be seen that in implementing Aswaja teachings, especially in various faculties, several problems can be encountered mainly due to the diversity of students from both schools, regions, countries, religions, cultures and customs so that the strengthening of character education through aswaja can be found various dynamics in the implementation.

Based on this background, the researcher was interested in examining how the integration of Aswaja teachings was used as a concept of strengthening character education in universities. 


\section{B. Teoritical Framework}

Character according to language means habit, whereas according to terms, character is a system of beliefs and habits that direct the actions of an individual. If knowledge about a person's character can be known, then it can be known that the individual will behave under certain conditions. Other concepts related to character are paedagogie and paedagogiek. Paedagogie means education, and paedagogiek means education. $^{3}$

Character basically refers to a series of attitudes, behaviors, motivation and skills. ${ }^{4}$ Scerenco provides a definition of character as an attribute or characteristics that shape and distinguish personal characteristics, ethical characteristics, and mental complexity of a person, a group or nation. ${ }^{5}$

Basically the formation of character can be influenced by three types of interrelated parts, namely moral knowledge, moral feeling, and moral behavior. ${ }^{6}$

The definition of character education is an effort to educate children to be able to make wise decisions and practice

\footnotetext{
${ }^{3}$ M. Mahbubi, Pendidikan Karakter: Implementasi Aswaja Sebagai Nilai Pendidikan Karakter, (Yogyakarta: Pustaka Ilmu, 2012), page 38

4 Zainal Aqib dan Sujak. Panduan dan Aplikasi Pendidikan Karakter. (Jakarta: Gaung Persada Press, 2011), page.2

${ }^{5}$ Muclas Samani dan Hariyanto, Pendidikan Karakter Konsep dan Model, (Bandung: Alfabeta, 2012),Page. 2

${ }^{6}$ Thomas Lickona, Pendidikan Karakter Panduan Mendidik Siswa Menjadi Pintar dan Baik, (Bandung: Nusa Media, 2008), page. 72
} 
them in daily life, so that they can make a positive contribution to their environment. ${ }^{7}$

Character education is also mentioned as an effort to cultivate intelligence in thinking, appreciation in the form of attitudes, and practice in the form of behavior that is in accordance with the noble values that are his identity, manifested in interaction with his God, himself, society and environment. $^{8}$

Ahlusunnah Waljamaah can be identified from three basic words, namely ahl, as-sunnah and al-jama'ah. Ahl can be interpreted as family, family, close relatives, class or followers. As-sunnah can be interpreted as a path and behavior. Aljama'ah is interpreted as a person who has perfect exemplary qualities based on the Qur'an and al-Sunnah, such as Abu Bakr, Umar, Usman and Ali. ${ }^{9}$

Ahlusunnah Waljamaah (Aswaja) is defined as a group that adheres to and practices the teachings of Islam taught and practiced by the Prophet Muhammad and his companions. ${ }^{10}$

Basically the Ahlusunnah Waljama'ah teachings cover the fields of aqeedah, syari'ah, akhlak and tasawuf. Aqeedah is

7 Ratna Megawangi, Pendidikan Karakter, Solusi yang Tepat untuk Membangun Bangsa, (Bogor: Indonesia Heritage Foundation, 2004), page. 63

${ }^{8}$ Zubaedi, Desain Pendidikan Karakter: Konsepsi dan Aplikasinya dalam Lembaga Pendidikan, (Jakarta: Kencana, 2011), page.17

9 Muhyidin Abdusshomad, HUJJAH NU Akidah-AmaliyahTradisi (Surabaya: khalista 2008),page. 32

10 Nur Cholid, Pendidikan Ke-NU-an Konsepsi Ahlusunnah Waljamaah, Annahdliyah, (Semarang: Presisi Cipta Media, cet.1, 2017), page. 1 
closely related to faith which means language believes, but for Ahlusunnah Waljama'ah's teachings that faith needs to be spoken orally and practiced in deeds is not only recognized in the heart. The field of Shari'ah or the study of the law which was established by Allah for his servants by mediating between His Apostles. In the field of shari'ah, Ahlusunnah's understanding of Waljama'ah acknowledged the truth of the four madzab, both Hanafi, Maliki, Syafi'i and Hambali. Determination of Islamic law according to the Ahlusunnah Waljama'ah school is based on four things, namely the Koran, As-Sunnah, Ijmak and Qiyas.

The field of morality is a study that deals with behavior that comes from an inner attitude or soul. The scope of morality is very large and extensive, which includes various things such as the nature of patience, simplicity, humility, honesty, holding/ keeping promises, being helpful, avoiding arrogant, wasteful, naughty and others. The Prophet positioned the morality as the key to safety and benefit both in one's own life, as well as in the life of society and the state. The field of Sufism study is related to the mental attitude and state of one's soul. The teachings of Sufism guide so that the quality of one's worship is truly perfect and recognizes the nature of man as a weak servant and always rests and surrenders to Allah SWT.

\section{Research Methods}

This research is a field research with a qualitative research approach. Qualitative research is a study whose results 
are more concerned with the interpretation of data found in the field. ${ }^{11}$ This study describes the concept and implementation of strengthening character education through the integration of Aswaja teachings at the research sites.

The data source in this study consisted of primary data sources and secondary data sources. Primary data or first-hand data are data obtained directly from research subjects, including the Director of the Aswaja Center, Head of Academic Affairs, Head of Student Affairs, and Chair of LP2M. Secondary data was obtained from various parties related to the implementation of Aswaja, namely lecturers and students. Secondary data is supporting data in addition to the primary data that has been obtained from the results of the study.

Data collection in this study uses several techniques, namely observation, interviews, and documentation. Observations were made to see a direct picture of the implementation of strengthening character education at the research site. Interviews are used to explore data in depth related to research problems, while documentation is used to add various data in the form of writing, pictures, archives, regulations and so forth.

Data analysis in this study uses descriptive analytical methods. Qualitative descriptive analysis is done by using existing words and facts. Descriptive is intended to describe the problem solving that is now based on data, which

${ }^{11}$ Sugiyono, Metode Penelitian Kuantitatif, Kualitatif, dan R\&D, (Bandung: Alfabeta, cet 17, 2012), page.7 
simultaneously presents data, analyzes and interprets the data in depth, so that the description of the concept and implementation of strengthening character education at the research location can be displayed empirically.

\section{Research Result}

Wahid Hasyim University Semarang is one of the private universities in Semarang that is very concerned with character building for its students. Wahid Hasyim University was founded in 2000 based on Aswaja teachings as the foundation for establishing higher education institutions. Wahid Hasyim University has 3 main campuses, namely Campus 1, located on Street Menoreh Tengah X / 22 Sampangan, Campus 2 is located in Kalipancur and Campus 3 is located in Gunungpati. The total number of students in 2018 was recorded at 10,105 from various regions in Indonesia and from various countries in the world such as Iraq, Afghanistan and Thailand

Besides Wahid Hasyim University students from various regions, they also came from various ethnic backgrounds, religions, races, customs and different customs so that it became a great potential for the university to be able to progress and develop into one of the most populous and global universities. This is in line with the university's vision to become a university that excels in transforming science, technology and art with the Islamic values of Ahlusunnah wal Jamaah in 2025. 
Wahid Hasyim University Semarang has 9 faculties namely the Faculty of Law, Faculty of Engineering, Faculty of Pharmacy, Faculty of Medicine, Faculty of Islamic Religion, Faculty of Economics, PJKR Faculty, Faculty of Social and Political Sciences, and Faculty of Agriculture. In addition to having 9 faculties, there are also Post-graduate programs for both the S2 and S3 levels. Aswaja's teachings as the foundation for organizing education at Wahid Hasyim University in Semarang are certainly held in the unit with a variety of activities related to religion.

Wahid Hasyim University Semarang as one of the universities based on the Aswaja teachings emphasizes that all graduates must be aswaja-characterized graduates, namely graduates who have cognitive intelligence, also have spiritual intelligence in accordance with the field of study itself.

Aswaja's teachings are related to the fields that are the center of the study, namely the aqeedah, syari'ah, ahlaq and tasawuf fields. Looking at the field of study, of course the concept of aswaja teaching as strengthening character education is also related to strengthening in the field of student study. The concepts relating to various fields of students are introduced to all students, both those who are Muslim and those who are religious other than Islam. This is a necessity because Aswaja is a teaching that becomes the spirit of Wahid Hasyim University in instilling and strengthening character for students. It's just that in its delivery it is certainly done with full tolerance and does not impose for students who are not Muslim. 
The field of aqeedah relating to faith is taught in accordance with Aswaja's main points in the field of aqeedah for example: God has a destiny for humans, but humans have a part to make efforts, so that in this life humans do not just surrender to their circumstances. This concept is also taught in accordance with the scientific field of students in various majors, for example for Medical students taught the concept that God has a destiny for humans, so that those who have the right to take one's life are only Allah. A doctor still tries to provide the best help, but still the human life is in God's hands. In the same study can also be taught to Agricultural students, although to grow plants is the power of God, but humans also should not surrender as long as they plant crops, humans also have to choose seeds and how to plant and care for plants well and of course other concepts in various study according to each faculty.

Aswaja's teachings on aqeedah can be seen that Ahlusunnah Waljamaah is not easy to forgive humans, in imitating the life pattern of the Prophet and his companions flexibly so that it can be adapted to the times as long as it does not violate Islamic law, Aswaja believes that the Qur'an is the word of God and not creature. Aswaja also believes that Allah has 20 mandatory qualities, 20 impossible traits and 1 jaiz trait. The person who believes in the teachings of Aswaja will enter Paradise and the justice of Allah appears when God places something in its place. 
Broadly speaking the aqeedah teachings in the Aswaja are taught to students according to their respective beliefs and according to the study of students' knowledge, so that the study is not sacred with regard to Faith in God but the most important thing is their words and deeds in believing in the Creator.

Another area that has been studied in Aswaja teachings is the Shari'ah field. Shari'ah or relating to the law that Allah decreed for his servant by the intermediary of his Apostle. This concept is taught by students as a provision when they are already involved in community life. The study was also adapted to the respective scientific fields. For example, in the Faculty of Medicine, the correct concept is related to various problems that occur in the medical world in accordance with Islamic law and several opinions from various madzab, for example the law of providing vaccines for toddlers, family planning law in Islam and its influence on human health, the law of giving medicines which comes from goods that are forbidden by Allah and other studies relating to the world of health.

Other studies used as discussions in the field of Shari'a, for example in the Faculty of Islamic Religion, can be studied from various problems related to polygamy, the study of jihad, the law of usury, association in Islam and so on. Other studies in the field of shari'a can also be studied in other faculties such as pharmacy and engineering, especially related to materials that can be used in the manufacture of drugs or equipment or machines that do not have adverse effects on humans. The Shari'ah study in the Aswaja perspective teaches students that 
in completing Islamic law besides holding on to the opinions of four schools of thought it is also based on the Koran, AsSunnah, Ijmak and Qiyas. Thus students have a broad view in determining everything that is permissible and not permissible in Islamic teaching rules more deeply.

The field of study in addition to aqidah and syari'ah, which is not less important, is the field of morality. Moral or means character, character or often interpreted manners or ethics and decency. This study of morality is carried out by habituating students to speaking, behaving, behaving and dressing. In the regulations for students it is emphasized that students must obey the rules, especially in speaking, behaving and wearing clothes in accordance with the norms and rules of the university. For example, having to wear formal clothing that does not show the genitals of both men and women, is not permitted to wear a veil and clothing that is not as appropriate reflects students who have good character.

The final field of study is related to Sufism. Sufism teaches that the Islamic quality of a person is truly perfect, also guiding mankind about the nature as a weak and always leaning servant, surrendering to God in every act. This study teaches the concept that students after trying to do everything must have good quality by submitting the best results according to Allah SWT.

The concept of strengthening character education through Aswaja teachings is carried out in a container named Aswaja Center. Aswaja Center has the main task in managing 
religious activities in the circle of Wahid Hasyim University, Semarang. The Aswaja Center was established in 2017 by seeing the growing field of student studies in various fields. The activities carried out by the Aswaja Center are related to regular weekly and monthly studies and are related to guidance and consultation related to religious practices. Thus students have a place to express their aspirations and thoughts and can even discuss and exchange thoughts to discuss various problems that are developing in the community in accordance with the right Islamic law, not from mere assumptions.

Strengthening character education at Wahid Hasyim University in Semarang is of course directed through the Tri dharma activities of higher education, both in educational activities, research and scientific publications as well as community service activities.

Strengthening the character of educational activities is carried out through habituation and good example from existing educators and education staff. Habit is done by activities of smile, greetings, salim, courtesy to educators and education staff so that students have a habit of respecting others, especially for older people. Exemplary teaching staff and education staff from various things, both from speech, attitude, behavior and polite manner of dress.

Organizational culture is also emphasized to form students who are strong and ready to face the challenges of the times. Some supporting activities include habituation in good organization and basic leadership activities for students. In 
addition to the activities carried out on campus, it is also held outside the campus and by cooperating with various other universities, so that students will be accustomed to working with various groups and can organize wherever they are in any conditions. This is also because students will return to the community and have a big contribution in building and advancing the community.

Student activities are carried out through various activities such as scouting, sports, writing and art activities. These activities are specifically accommodated by student affairs in various student activity units, so that they can still direct students in activities that are in accordance with the Aswaja teachings. The Student Activity Units in Wahid Hasyim University Semarang are Student Executive Board, Student Representative Council, Student Leadership Department, Student Press Institute, Scout, PMI Voluntary Corps, Art Creative UKM, Photographic and Cinematographic Community UKM, Student Choir UKM, Jami'iyah Quro wal Huffadz UKM, UKM Language, Sports UKM, Pencaksilat UKM, Mapala UKM and Student Cooperative.

In fact, students are directed to choose activities in the Student Activity Unit according to the talents, interests and abilities of each student. Although there is no coercion, students are directed to follow one of the several existing Student Activity Units. By participating in one of the Student Activity Units, there will be a lot of knowledge, experience and 
various provisions that are very important for students in addition to being obtained on the lecture bench.

Habituation in organizational life, daily activities other than those carried out on campus, are also directed at the boarding school environment. Luhur Islamic Boarding School Wahid Hasyim is a support for religious activities for students in Wahid Hasyim University. Studies on religiousness are also carried out in Islamic boarding schools as an effort to strengthen character education in addition to campus activities. In addition, habituation as in Aswaja teachings is also done by building good cooperation with the community around the campus.

Cooperation activities are carried out because the university understands how important the role of the community is in advancing student activities and university activities in general. These activities are directed to be able to help the surrounding community which is usually done by means of cleaning the community environment, bazaar activities, blood donor activities, posyandu, the elderly and other activities that benefit the community. The activities carried out in the community are sought so that later students can have the same habits and can be applied in their daily lives, especially in the family and community later.

Research activities and scientific publications are also directed according to Islamic teachings so that research activities are directed not to leave the corridors that are prohibited in Islam itself. Research activities and scientific 
publications are actually carried out in accordance with the field of study of each faculty, so that the selection of research themes can vary according to studies in various faculties.

Community service activities are also directed according to the Aswaja teachings. One of the community service activities is the Community Service Program (KKN) which is routinely carried out every year. In each theme of community service activities carried out, it must emphasize the goal so that students have aswaja characters. Examples of KKN activities held by LP2M in August 2018 took the theme of the Role of Students in Community Empowerment to Realize Healthy Cities Based on Aswaja. In every KKN activity held every year, the Aswaja character is always emphasized on each theme taken. This is because every research and community service activity, the Aswaja character that makes students become moderate, tolerant, balanced, fair and soulless, can be embedded in the minds of every student.

Community service activities besides $\mathrm{KKN}$ activities are also carried out as a form of service and obligations that must be fulfilled for each student. Other activities that are routinely carried out are blood donor activities, fundraising for victims of disasters, which have recently been carried out such as raising funds for victims of the Earthquake in Lombok and other humanitarian activities such as cleaning roads and the community environment.

In addition to being equipped with the ability and understanding of various sciences, students are also equipped to 
research and conduct community service, so that this will greatly help students when they enter the community.

The implementation of Aswaja teachings is carried out from the beginning of the lecture to graduation activities, so that the activities of students are carried out through the orientation of the religion for new students, habituation for students and understanding of students at the end of the student's study period. Orientation activities for new students are mandatory activities that must be followed by every new student. This activity was carried out by the university and the respective faculties. The aim of the religious orientation course is to provide provisions for new students related to the fields of student study that students must understand and practice well while they are students and later when they return to society.

In addition to religious orientation activities for new students, several routine studies on religious health are also carried out weekly and monthly. This activity was carried out to see some interesting and necessary studies for all students, so that the field of study is usually adjusted to the respective scientific fields in each faculty. Some examples of religious studies conducted usually discuss phenomena that are happening among students, for example courtship law, law using veils, studies on reproductive health, studies of gender and various studies related to religious radicalism.

In addition to the student orientation activities, the routine study of workmanship is also carried out in the education field, which is integrated in the subjects of each 
faculty and students' courses become compulsory subjects for students. Aswaja which is integrated in the courses of each faculty means that each subject taught to students must be linked to the field of student study both in terms of aqeedah, syari'ah, akhlaq and tasawuf.

Student subjects that are compulsory for students are courses that must be taken by each student at the Wahid Hasyim University in Semarang, but students in each faculty are usually different in their implementation, namely in faculties other than the faculties of Islamic religion. , fair, moderate and so on. This is because in faculties other than the faculties of Islamic Religion, students generally have diverse religions, so aswaja is packaged in such a way according to the themes of the study in general.

The implementation of strengthening character education through the integration of Aswaja teachings certainly has many problems, especially because of the different input of students, thus making students' understanding of the concept of students also different. Other problems also appear from the rise of several other idealistic threats, especially from social media which if not properly resisted, will damage and threaten the Aswaja teachings themselves. Other problems also arise especially in understanding students from other countries who generally have different cultures and understandings of Islam, so it is difficult to plant aswaja teachings on foreign students. 


\section{E. Conclusion}

Based on the results of the research that the researchers did related to the integration of Aswaja's teachings as a concept of strengthening character education in Higher Education can be concluded as follows:

1. The concept of Aswaja teaching as strengthening character education carried out at Wahid Hasyim University is carried out in accordance with the concept of Aswaja teaching both in the fields of aqeedah, syari'ah, akhlaq and tasawuf which are developed in accordance with scientific studies in each faculty. Strengthening character education is carried out through the Aswaja Center which regulates every religious activity.

2. The implementation of Aswaja teachings as a reinforcement of character education at Wahid Hasyim University in Semarang is done through habituation in various activities, both educational activities, research and scientific publications as well as community service activities. The implementation of Aswaja teachings was also carried out through guidance and consultation activities related to religious practices and the integration of Aswaja teachings in subjects that were adjusted to the study fields of each faculty. 


\section{REFERENCES}

Abdusshomad, Muhyidin, HUJJAH NU Akidah-AmaliyahTradisi, Surabaya: khalista 2008.

Aqib, Zainal dan Sujak. Panduan dan Aplikasi Pendidikan Karakter, Jakarta: Gaung Persada Press, 2011.

Cholid, Nur, Pendidikan Ke-NU-an Konsepsi Ahlusunnah Waljamaah, Annahdliyah, Semarang: Presisi Cipta Media, cet.1, 2017.

Lickona, Thomas, Pendidikan Karakter Panduan Mendidik Siswa Menjadi Pintar dan Baik, Bandung: Nusa Media, 2008 .

M. Mahbubi, Pendidikan Karakter: Implementasi Aswaja Sebagai Nilai Pendidikan Karakter, Yogyakarta: Pustaka Ilmu, 2012.

Megawangi, Ratna, Pendidikan Karakter, Solusi yang Tepat untuk Membangun Bangsa, Bogor: Indonesia Heritage Foundation, 2004.

Samani, Muclas dan Hariyanto, Pendidikan Karakter Konsep dan Model, Bandung: Alfabeta, 2012.

Sugiyono, Metode Penelitian Kuantitatif, Kualitatif, dan R\&D, Bandung: Alfabeta, cet 17, 2012.

Tim Pendidikan Karakter Ditjen Dikti 2010

Wibowo, Agus, Pendidikan Karakter di Perguruan Tinggi, Yogyakarta: Pustaka Pelajar, cet.1, 2014. 
Zubaedi, Desain Pendidikan Karakter: Konsepsi dan Aplikasinya dalam Lembaga Pendidikan, Jakarta: Kencana, 2011. 